\title{
Influencing Factor of Peripheral Performance of Knowledge-based Employee Based on Organizational Commitment
}

\author{
Bin Shen \\ College of Business Administration \\ Fujian Jiangxia University \\ Fuzhou, China 350108
}

\begin{abstract}
Based on the important role of knowledge-based employees' peripheral performance behaviors in the enterprise, from the three dimensions of emotional commitment, normative commitment and continuous commitment, there is a significant correlation between organizational commitment and the performance of knowledge-based employee. It has provided reasonable advice for the human resources management of the knowledge-based employee.
\end{abstract}

Keywords-knowledge-based employee; organizational commitment; peripheral performance

\section{INTRODUCTION}

In the era of knowledge economy, the enterprise competition has turned into the competition for knowledge and talent. 8 The performance of knowledge-based employee becomes an important part of enterprise operating performance. The work performance of knowledge-based employee includes two parts: task performance and peripheral performance. The performance appraisal of knowledge-based employee focuses on task performance, and does not pay attention to the peripheral performance of knowledge-based employee. The organization also lacks factors to promote the peripheral performance of employees. The contribution of knowledge-based employees beyond job responsibilities is often not recognized and encouraged, resulting in a decrease in the willingness of knowledge-based employees to contribute to peripheral performance, lacking the teamwork spirit, enthusiasm and initiative in their work. There is an invisible bond between the work behavior of knowledge-based employees and the peripheral performance, and organizational commitment is the key to maintain this bond. [1] Therefore, it is of great practical significance to explore the influence of organizational commitment on the peripheral performance of knowledge-based employees and promoting the peripheral performance of knowledge-based employees.

\section{LITERATURE REVIEW}

\section{A. Relevant Theory of Knowledge-based Employee}

The famous management master Peter Drucker (1956) believes that employees need to have a certain basic knowledge of the profession. They can translate the theory into practice through the application of this knowledge or information [2]. These employees should be called knowledge-based employees. With the transformation and development of society, the cognition of "knowledge type" by different scholars and organizations has also changed The perspectives and levels of analysis are not the same. And the defined concept of knowledge-based employee is also different. The "capability theory", "theory of learning ability" and "professional theory" of knowledge-based employee are put forwarded. This paper defines knowledge-based employees as talents whose education level is higher than the junior level. These knowledge-based employees have certain technologies and theories, and can bring new benefits to the enterprise.

\section{B. Relevant Theory of Organizational Commitment}

American sociologist Becker first proposed the concept of organizational commitment in his research. He regarded organizational commitment as a psychological activity of employees, which aims to show that employees will pay their own emotions, time, energy, etc. to satisfy the willingness of staying with the organization. [3] From the perspective of their own research, scholars from different countries have proposed different dimensional models for organizational commitment. There are five dimensions: one dimension, two dimensions, three dimensions, four dimensions, five dimensions. The corresponding organizational commitment measurement scale has been developed. The most influential are the OCQ questionnaire issued by owday et al., Meyer and Allen's 3-OC scale. This paper mainly uses the three-dimensional theory of organizational commitment proposed by Allen and Meyer. The organizational commitment can be divided into three types: emotional commitment, continual commitment and normative commitment. 


\section{Related Theory of Peripheral Performance}

Based on the division of job performance, Borman and Motowidlo formally proposed the definition of peripheral performance. "The organizational responsibility statement does not formally make the stipulation. The employees consciously assume the behaviors that contribute to the overall performance of the organization, which consist of social and psychological background of the organization and have no direct relationship with the production and service activities of the organization." [4] With the change of enterprise management practice activities and the deepening of theoretical research, the academic circles have proposed different dimensional models for the division of peripheral performance structure. There are two dimensions, three dimensions, five dimensions and six dimensions. This paper mainly adopts the classic two-dimensional division method of Scot and Motowidlo, that is, the peripheral performance includes two dimensions: interpersonal promotion and work dedication. [5]

\section{Relevant Theory of Organizational Commitment and Peripheral Performance}

Through the combing of domestic and foreign related literature on organizational commitment and peripheral performance, we can find that there is not much research on this aspect. The notion of the relationship between organizational commitment and peripheral performance is not uniform. Through empirical research, Bernard proves that emotional commitment and normative commitment have positive correlations with peripheral performance and its two dimensions. However, continual commitment has a negative correlation with interpersonal promotion and work dedication. [6] Domestic research on organizational commitment and peripheral performance is still in its infancy. When studying the relationship between college teachers' job performance and organizational commitment, $\mathrm{Hu}$ Jian and Mo Yan find that the two dimensions of emotional commitment and normative commitment in organizational

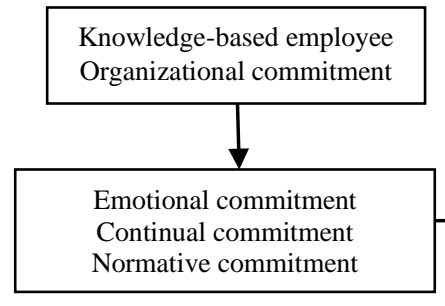

Fig. 1. Research model.

\section{B. Analysis of Empirical Data}

In this study, a total of 280 questionnaires were distributed to employees with a college degree or above in Beijing, Shanghai, Xiamen, Shenzhen and Jinan and other cities. A total of 270 questionnaires were actually collected. Excluding some unqualified questionnaires, the final valid questionnaire was 265 . The recovery rate of the questionnaire in this study was $96.43 \%$, and the effective rate of the questionnaire was $98.15 \%$. The gender proportion of male and female employees is appropriate. The education, commitment are significantly correlated with the peripheral performance of college teachers. [7]

Based on the increasingly important core position and unmanageable reality of knowledge-based employee in the enterprise, and the important role of peripheral performance behaviors in the enterprise, this paper tries to explore the impact of organizational commitment on the peripheral performance of knowledge-based employee from the internal mechanism forming from three different dimensions of organizational commitment and peripheral performance. And it can provide practical guidance for human resources management of knowledge-based employees.

\section{RESEARCH DESIGN AND EMPIRICAL ANALYSIS}

\section{A. Research Design}

This study adopts the three-dimensional theory of organizational commitment and the two-dimensional theory of peripheral performance to build a research model.

As shown in "Fig. 1". The Organizational Commitment Scale contains three dimensions of organization commitment such as emotional commitment, retention commitment, and normative commitment. The Peripheral Performance Questionnaire contains two dimensions: interpersonal promotion and work dedication. The following assumptions are made:

H1: The education level of knowledge-based employee is positively related to the three dimensions of organizational commitment;

$\mathrm{H} 2$ : The emotional commitment of knowledge-based employee is positively related to peripheral performance;

H3: The normative commitment of knowledge-based employee is positively related to peripheral performance;

H4: The continual commitment of knowledge-based employee is positively related to peripheral performance.

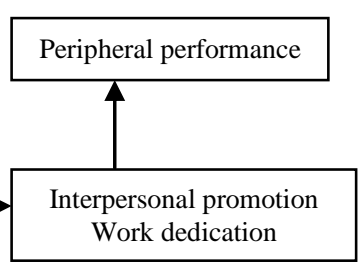

age, and length of service are also in line with the current proportion of the talent market. This questionnaire has certain representativeness.

1) Reliability detection: In order to ensure the reliability of the answer sheet, the reliability analysis of the answer sheet is required. This paper uses the SPSS19.0 software to make the data analysis of the sample data. The Cronbach coefficient is used to verify the reliability of the answer sheet. It can be seen from the table that the Cronbach' $\alpha$ values of emotional commitment, continual commitment, 
and normative commitment are all greater than 0.7, indicating that the results of this survey have high stability and reliability.

TABLE I. ANALYSIS OF CRONBACH'A COEFFICIENT OF SURVEY SAMPLE DATA

\begin{tabular}{|l|l|l|}
\hline \multicolumn{1}{|c|}{ Research variable } & \multicolumn{1}{|c|}{$\begin{array}{c}\text { Number of } \\
\text { items }\end{array}$} & $\begin{array}{c}\text { Cronbach' } \boldsymbol{\alpha} \\
\text { coefficient }\end{array}$ \\
\hline Emotional commitment & 7 & 0.828 \\
\hline continual commitment & 6 & 0.771 \\
\hline Normative commitment & 5 & 0.880 \\
\hline Interpersonal promotion & 7 & 0.838 \\
\hline Work dedication & 8 & 0.841 \\
\hline
\end{tabular}

2) Validity test: In this study, factor analysis was used to analyze the validity of the questionnaire with KMO value method and Bartley's spherical test analysis tool. It can be seen from "Table II" that the KMO value of the questionnaire is 0.814 , the approximate value of the Bartlett spherical test X2 is 1486.215 , the df (degree of freedom) is 184, and the Sig (significance) is 0.000 , indicating that the questionnaire has good structural validity.

TABLE II. KMO TEST AND BARTLETT SPHERICAL TEST FOR SURVEY SAMPLE DATA

\begin{tabular}{|c|l|c|}
\hline \multicolumn{2}{|c|}{$\begin{array}{c}\text { Kaiser-Meyer-Olkin Measure of } \\
\text { Sampling Adequacy }\end{array}$} & $\mathbf{. 8 1 4}$ \\
\hline \multirow{3}{*}{ Bartlett spherical test } & X2 & 1486.215 \\
\cline { 2 - 3 } & df & 184 \\
\cline { 2 - 3 } & Sig & .000 \\
\hline
\end{tabular}

3) Descriptive statistics of variables: Descriptive statistics of the organizational commitment variables for this study are shown in "Table III". It can be seen from the table that the mean of emotional commitment, retention commitment, and normative commitment are less than 3 , indicating that the organizational commitment of knowledge-based employee is generally not high.

TABLE III. ORGANIZATIONAL COMMITMENT VARIABLE STATISTICS

\begin{tabular}{|l|l|l|l|}
\hline & \multicolumn{1}{|c|}{$\begin{array}{c}\text { Emotional } \\
\text { commitment }\end{array}$} & $\begin{array}{c}\text { Continual } \\
\text { commitment }\end{array}$ & $\begin{array}{c}\text { Normative } \\
\text { commitment }\end{array}$ \\
\hline Mean & 2.2518 & 2.4849 & 2.3298 \\
\hline $\begin{array}{l}\text { Standard } \\
\text { deviation }\end{array}$ & 0.4022 & 0.3647 & 0.963 \\
\hline
\end{tabular}

Descriptive statistics of the peripheral performance variables for this study are shown in "Table IV". It can be seen from the table that the mean of interpersonal promotion and work dedication is also less than 3 , indicating that the peripheral performance of knowledge-based employee is generally low.

TABLE IV. PERIPHERAL PERFormanCE VARIABLE STATISTICS

\begin{tabular}{|l|l|l|}
\hline & $\begin{array}{c}\text { Interpersonal } \\
\text { promotion }\end{array}$ & $\begin{array}{c}\text { Work } \\
\text { dedication }\end{array}$ \\
\hline Mean & 2.3040 & 2.3321 \\
\hline $\begin{array}{l}\text { Standard } \\
\text { deviation }\end{array}$ & 0.352 & 0.3285 \\
\hline
\end{tabular}

4) Correlation analysis: It can be seen from "Table V" that there is a correlation among the educational level, the emotional commitment, continual commitment, and normative commitment in the demographic variables, and the correlation with the emotional commitment is the strongest. From "Table VI", it can be concluded that there is a positive correlation between knowledge-based employee organizational commitment and peripheral performance, and the Person correlation coefficient value is $0.34^{* *}$. This indicates that the correlation between knowledge-based employee organizational commitment and peripheral performance is extremely significant. In addition, interpersonal promotion and work dedication and organizational commitment of peripheral performance are also positively correlated, and the Person correlation coefficient values are $0.30^{* *}$ and $0.30^{* *}$ respectively. The three dimensions of emotional commitment, continual commitment and normative commitment of organizational commitment are positively correlated to the interpersonal promotion and work dedication of peripheral performance. The relationship is significant.

Therefore, it can be concluded that the previous $\mathrm{H} 1, \mathrm{H} 2$, $\mathrm{H} 3$, and $\mathrm{H} 4$ assumptions are all true.

TABLE V. ANALYSIS OF THE CORRELATION BETWEEN EDUCATION LEVEL AND ORGANIZATIONAL COMMITMENT

\begin{tabular}{|l|l|l|}
\hline & & Education level \\
\hline Emotional commitment & Pearson (correlation) & $.175^{*}$ \\
\hline & Significance (bilateral) & .002 \\
\hline continual commitment & Pearson (correlation) & $.126^{*}$ \\
\hline Normative commitment & Significance (bilateral) & .022 \\
\hline & Pearson (correlation) & $.114^{*}$ \\
\hline & Significance (bilateral) & .025 \\
\hline
\end{tabular}


TABLE VI. ANALYSIS OF THE RELATIONSHIP BETWEEN ORGANIZATIONAL COMMITMENT AND PERIPHERAL PERFORMANCE

\begin{tabular}{|l|l|l|l|l|l|l|l|}
\hline & $\begin{array}{c}\text { Organizational } \\
\text { commitment }\end{array}$ & $\begin{array}{c}\text { Emotional } \\
\text { commitment }\end{array}$ & $\begin{array}{c}\text { Continual } \\
\text { commitment }\end{array}$ & $\begin{array}{c}\text { Normative } \\
\text { commitment }\end{array}$ & $\begin{array}{c}\text { Peripheral } \\
\text { performance }\end{array}$ & $\begin{array}{c}\text { Interpersonal } \\
\text { promotion }\end{array}$ & $\begin{array}{c}\text { Work } \\
\text { dedication }\end{array}$ \\
\hline $\begin{array}{l}\text { Organizational } \\
\text { commitment }\end{array}$ & 1 & & & & \\
\hline $\begin{array}{l}\text { Emotional } \\
\text { commitment }\end{array}$ & $0.22^{* *}$ & 1 & & & \\
\hline $\begin{array}{l}\text { continual } \\
\text { commitment }\end{array}$ & 0.32 & 0.27 & 1 & 1 & & \\
\hline $\begin{array}{l}\text { Normative } \\
\text { commitment }\end{array}$ & $0.20^{* *}$ & 0.24 & 0.42 & $0.31^{* *}$ & 1 & \\
\hline $\begin{array}{l}\text { Peripheral } \\
\text { performance }\end{array}$ & $0.34^{* *}$ & $0.33^{* *}$ & 0.23 & $0.32^{* *}$ & $0.33^{* *}$ & 1 \\
\hline $\begin{array}{l}\text { Interpersonal } \\
\text { promotion }\end{array}$ & $0.30^{* *}$ & $0.26^{* *}$ & 0.20 & $0.31^{* *}$ & $0.36^{* *}$ \\
\hline Work dedication & $0.29^{* *}$ & $0.27^{* *}$ & 0.25 & & $0.24^{* *}$ \\
\hline
\end{tabular}

\section{CONCLUSION AND RECOMMENDATIONS}

\section{A. Research Conclusion}

Based on the characteristics of knowledge-based employees, this paper explores the impact of organizational commitment on the peripheral performance of knowledgebased employee from three different dimensions: organizational commitment, continual commitment and normative commitment. The results of the study find that the education level of knowledge-based employee is significantly positively correlated with organizational commitment. The higher the level of education is, the higher the organizational commitment level of employees will be. The three dimensions of knowledge-based employees' organizational commitment and the peripheral performance are all at 0.01 . There is a significant positive correlation. The knowledge-based employees' emotional commitment is significantly positively correlated with peripheral performance. The knowledge-based employees' normative commitment is significantly positively correlated with peripheral performance. The knowledge-based employees' continual commitment is positively correlated with peripheral performance correlation.

\section{B. Management Recommendations}

1) Strengthening the standardized management of enterprises: Empirical studies show that the normative commitment of knowledge-based employees has a strong correlation with peripheral performance. The standardized management of the enterprise guarantees the reasonable economic and material conditions of the employees. [8] Knowledge-based employees have a strong sense of obligation and responsibility. When employees feel the support and responsibility of the company, employees will also assume the responsibility of standardization, abide by the rules and regulations of the company, and be strict with themselves. They can complete the work according to the requirements of the enterprise.

2) Building reasonable career development channel: Knowledge-based employees are relatively high in their academic qualifications and abilities, and their requirements for jobs are no longer only concerned with monetary compensation. [9] The career development space is undoubtedly a key factor for companies to retain and attract talent. Companies should assist employees in making reasonable career planning. The career development of employees should keep pace with the goals of corporate organization. The employees should achieve their goals while achieving the goals of the enterprise.

3) Paying attention to the construction of corporate culture: Knowledge-based employees pay more attention to corporate culture and work atmosphere in their work, and pay more attention to emotional and psychological satisfaction. [10] Companies should start by improving their emotional commitments, thereby improving their peripheral performance. The enterprise should actively create a channel that facilitates good communication among the employees. Through communication, it can enhance employees' trust and care for others. At the same time, the employees participate in management, enhancing employees' emotional commitment and promoting the peripheral performance.

\section{REFERENCES}

[1] Sun Lina. Research on peripheral performance management of employee based on organizational commitment [D]. Shandong Economic University. 2011.

[2] Peter.F. Drucker. Translated by Zhu Yanbin. Management Challenges in the 21st Century [M] Beijing: Mechanical Industry Press, 2009.

[3] Becker, H.S.1960.Notes on the concept of commitment[J].American Journal of Sociology.66:32-46.

[4] Borman,Molowidlo.Task performance and contextual performance:the meaning of personnel selection research[J].Human performance.1997,10(2):99-109.

[5] Scot, Molowidlo.Main and Interaction Effects of Task and Contextual Performance On Supervisory Reward Decisions[J].Journal Of Applied Psychology, 1999,84:602-609.

[6] Cao Jiali, Lu Mengqi, Li Li et al. Review of peripheral performance research [J]. Human Resource Management. 2016(5):292-295.

[7] Hu Jian, Mo Yan. Research on the Relationship between College Teachers' Organizational Commitment and Job Performance[J]. Journal of Zhejiang Sci-Tech University, 2005(12): 20-24.

[8] Shi Hongyan. Research on the relationship between employee identification and peripheral performance[J].Human Resources Development, 2015(18): 63-64. 
[9] Yu Nengchao. Research on the relationship between occupational calling and peripheral performance [D]. Dongbei University of Finance and Economics, 2017.

[10] Zhang Kewen. Research on Peripheral Performance Evaluation and Promotion Strategy of knowledge-based employees[J]. China Labor, 2015(6): 83-86. 